\title{
Keratin 18 is associated with a subset of older taste cells in the rat
}

\author{
Chunxiao Zhang, Murray Cotter, Anne Lawton, Bruce Oakley, Lianna Wong*, Qun Zeng \\ Department of Biology, University of Michigan, 3127 Natural Science Building, Ann Arbor, MI 48109, USA
}

Accepted in revised form: 2 June 1995

\begin{abstract}
All or nearly all intragemmal (elongated) cells of rat taste buds were immunopositive for keratins 7,8 , and 19. In contrast, keratin 18 was detected in $19 \pm 5$ cells per taste bud (mean \pm sd), or about $25 \%$ of the intragemmal cells. During taste bud development keratins 7, 8, and 19 were evident initially in polygonal cells and later in elongated taste cells. Keratin 8 appeared in vallate taste cells at P0 (postnatal day 0), followed by keratins 7 and 19 at P1, and keratin 18 at P2-P3. Keratin 18 was always limited to elongated cells. The assemblage of elongated taste cells comprising a taste bud began with a single elongated cell, rather than with the synchronous elongation of a cluster of cells. Developmental errors were observed at P2-P3, e.g., some vallate taste cells had a misoriented axis. In order to study the pace of keratin differentiation during cell turnover we injected bromodeoxyuridine (BrdU) into adult rats to monitor taste cell age. Keratin-19-positive intragemmal cells differentiated within 1 day. In contrast, keratin 18 was first detected in cells aged 3 days. Hence, both in taste cell development and replacement, keratin 18 was restricted to the older cells; it was the last taste cell keratin to become expressed during differentiation.
\end{abstract}

\section{Introduction}

Keratin expression changes as epithelial cells progressively differentiate $[9,15,19,21,27,33]$. The diversity of keratins and their transient expression make them the best differentiation markers of oral epithelial tissues [19, $20,30]$.

Epithelia are either simple (one layer) or stratified (multiple layers). Simple epithelia contain some combination of keratins $7,8,18$ and $19[18,19]$. These four keratins have been associated with taste buds $[1,13,15$,

* Present address: Department of Molecular and Cell Biology, University of California at Berkeley, Berkeley, CA 94720, USA

Correspondence to: B. Oakley
22-25, 31, 34, 35, 37]. Thus, both the morphology and the immunocytochemistry of the oral epithelium suggest that taste buds are islets of simple epithelia embedded in stratified squamous epithelia $[25,30,35]$.

Lane [15] was the first to report keratin 18 in taste buds (rat fungiform; monoclonal antibodies [MAbs] $L E 61$ and LE65). Sawaf et al. [31] confirmed these observations for human fungiform taste buds (MAb Ks 18.174). Takeda et al. [34] (MAb PKK3) and Toh et al. [35] (MAb LE61) observed keratin-18-like immunoreactivity in mouse vallate taste buds. In contrast to keratins 7,8 , and 19 , we report that keratin-18-like immunoreactivity is absent from $75 \%$ of intragemmal cells-the elongated cells within a taste bud $[13,25]$. We quantified the subset of taste cells that had keratin 18 and measured the timing of keratin 18 occurrence during development and cell replacement.

\section{Methods}

Tissue collection. Sprague-Dawley albino rats (Harlan Sprague Dawley, Indianapolis, IN, USA) were kept on a 12-h light: 12-h dark cycle and housed with ad libitum food and water. For tissue collection, neonatal rats (postnatal ages $0,1,2,3,4,7$, and $10 \mathrm{~d}$ ) were euthanized with carbon dioxide gas. Adult rats were deeply anesthetized with an i.p. injection of sodium pentobarbital (70 $\mathrm{mg} / \mathrm{kg} \mathrm{b.w.).} \mathrm{The} \mathrm{anesthetized} \mathrm{animals} \mathrm{were} \mathrm{perfused} \mathrm{intracardial-}$ ly with either $0.9 \% \mathrm{NaCl}$ solution containing $0.02 \%$ sodium heparin and $0.5 \%$ procaine hydrochloride or TRIS-buffered mammalian Ringer's solution [26], followed by acid alcohol fixative (70\% ethanol, $10 \%$ acetic acid).

Tongues were excised and immersed in acid alcohol fixative for at least $1 \mathrm{~h}$. Tongue tissue was cryoprotected in a mixture of $20 \%$ sucrose and the embedding compound OCT. Ten-micrometer-thick cryosections were cut at $-25^{\circ} \mathrm{C}$, mounted on gelatincoated slides, and stored at $-20^{\circ} \mathrm{C}$. The methods of animal care and euthanasia were approved by the University of Michigan Committee on the Use and Care of Animals.

Immunohistochemistry. The primary monoclonal antibodies (MAbs) were: MAb RCK105 to keratin 7 (Monosan, [28]); MAb 4.62 to keratin 19 (Sigma, [10]); MAb LE41 to keratin 8 (Amersham, [15]); MAb LE65 to keratin 18 (Amersham, [15]), MAb 

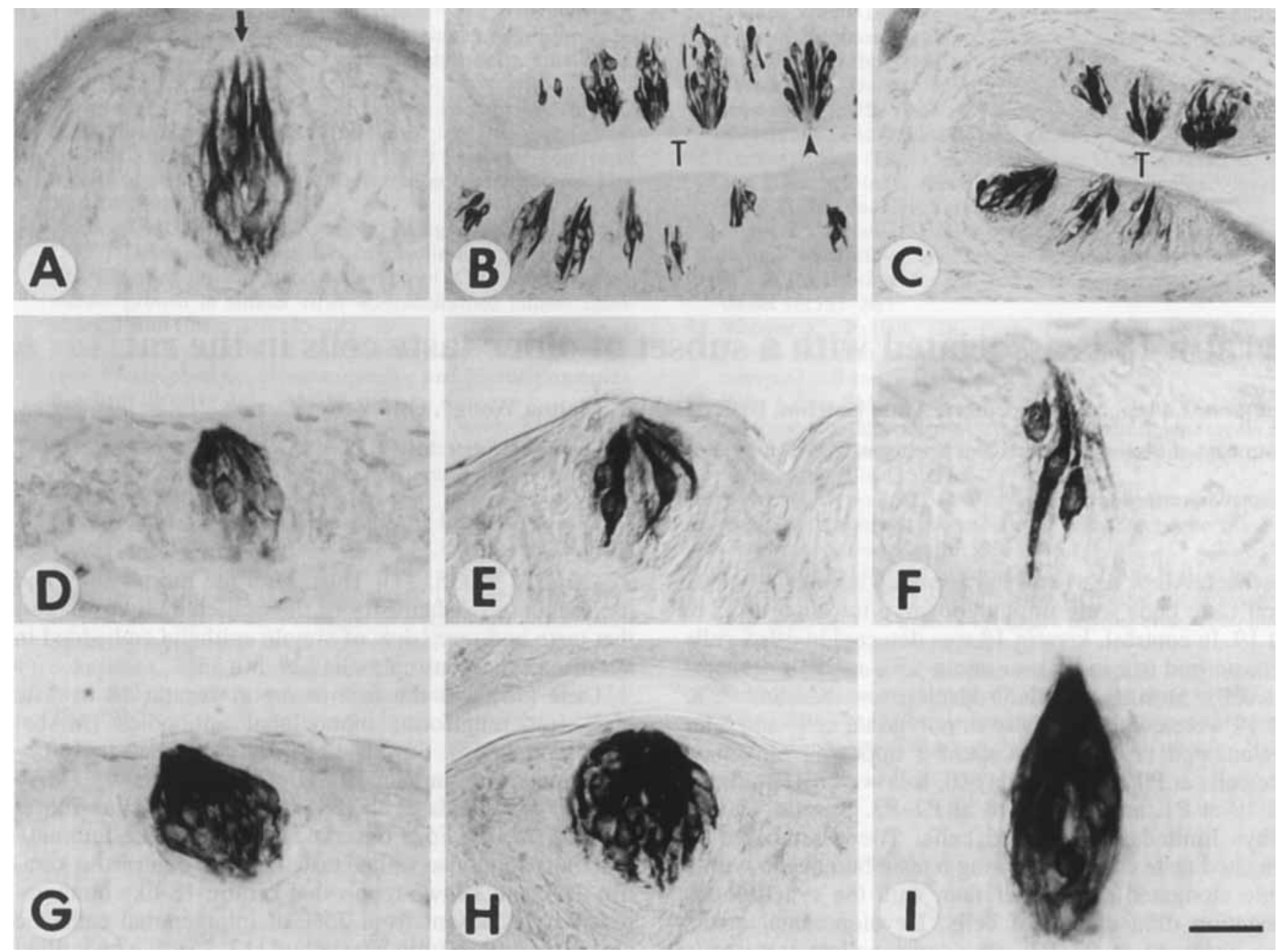

Fig. 1A-I. Keratin-18-like immunoreactivity is present in a subset of intragemmal cells in taste buds of: fungiform papillae (A), vallate papilla (B), foliate papillae (C), epiglottis (D), nasopalatine papilla (E), and palate (F). The arrow in $\mathbf{A}$ indicates the apical tips of keratin 18-positive intragemmal cells. In order to stimulate the apex of taste cells (arrowhead in B), taste solutions must enter the trenches $(T)$ of the foliate and vallate papillae. G Keratin 19 in an epiglottal taste bud. H Keratin 7 in a nasopalatine taste bud, I Keratin 8 in a taste bud of the palate. Scale bar in $I$ is $50 \mu \mathrm{m}$ for B, C and $20 \mu \mathrm{m}$ for other panels
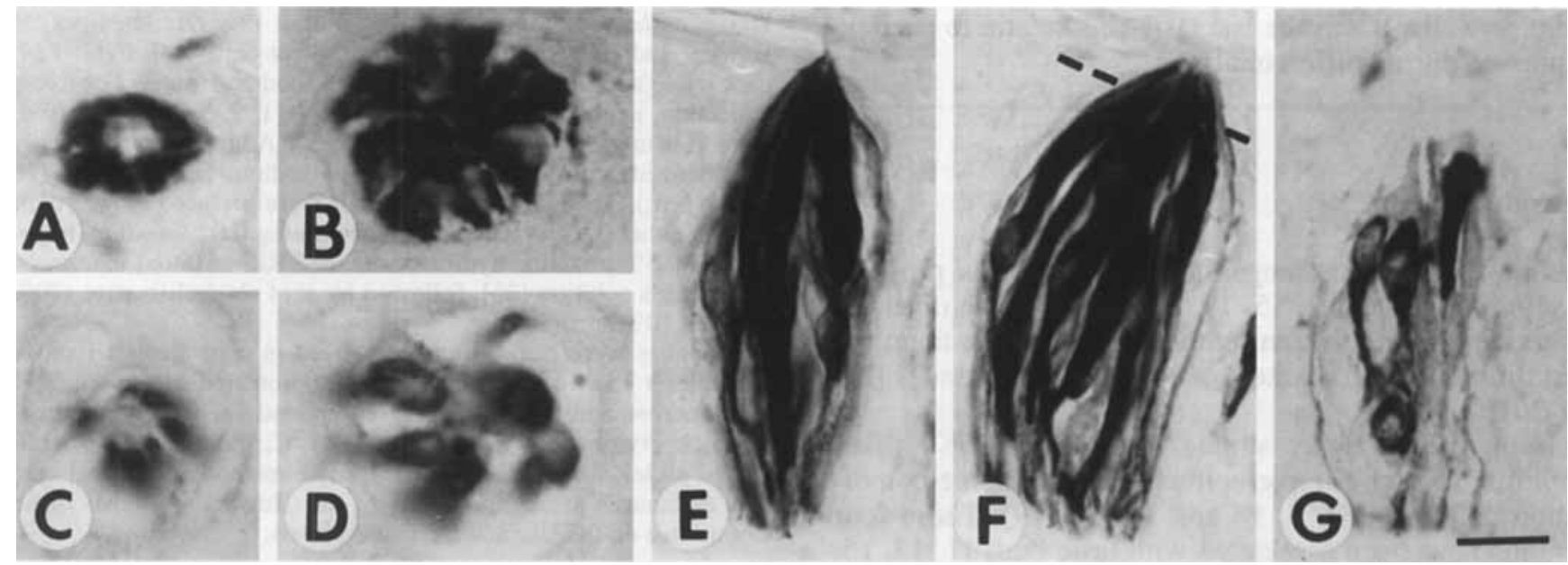

Fig. 2A-G. Keratin 19 immunoreactivity in a vallate taste bud cross-section that passed through (A) and immediately beneath (B) the taste pit. Keratin 18 immunoreactivity in a vallate taste bud cross-section through (C) and beneath (D) the taste pit. E-G
Three serial, longitudinal-sections of a vallate taste bud containing 23 keratin-18-positive cells. The dashed line in $\mathbf{F}$ indicates the approximate location of the base of the taste pit. Scale bar in $\mathbf{G}$ is $8 \mu \mathrm{m}$ for $\mathbf{A}-\mathbf{D}$ and $10 \mu \mathrm{m}$ for $\mathbf{E}-\mathbf{G}$ 


\section{K8}
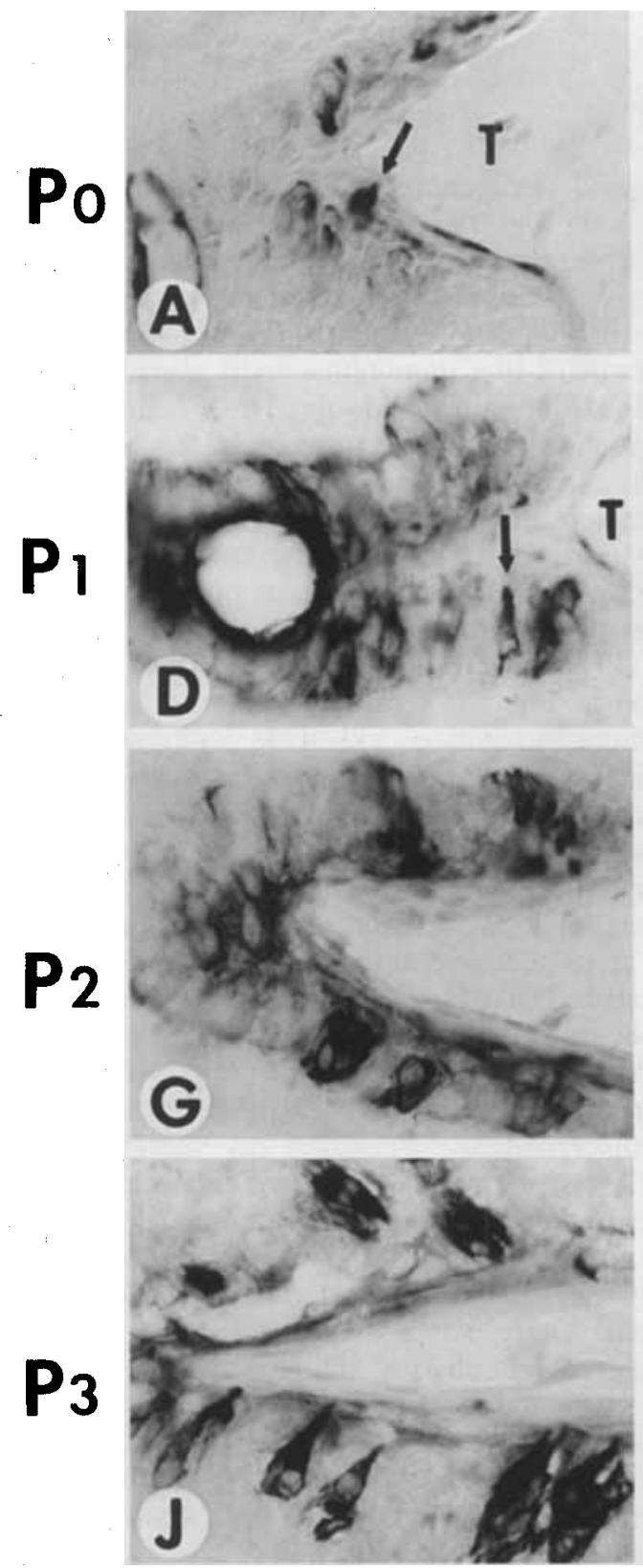

K7
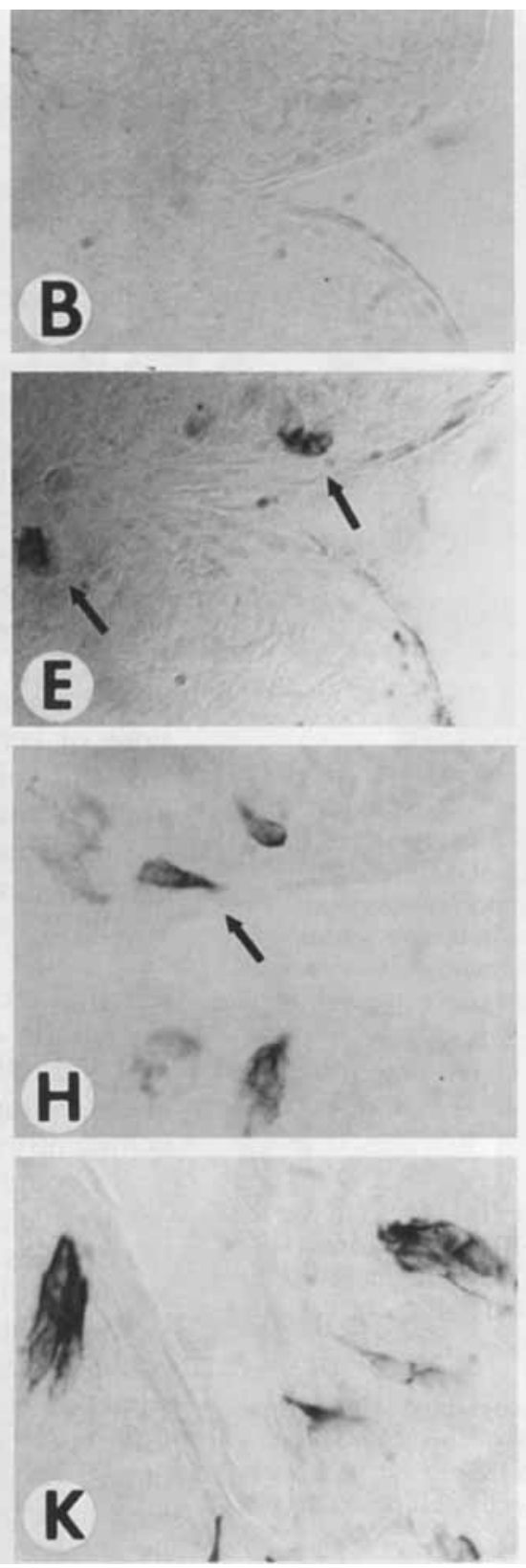

$\mathrm{K} 18$
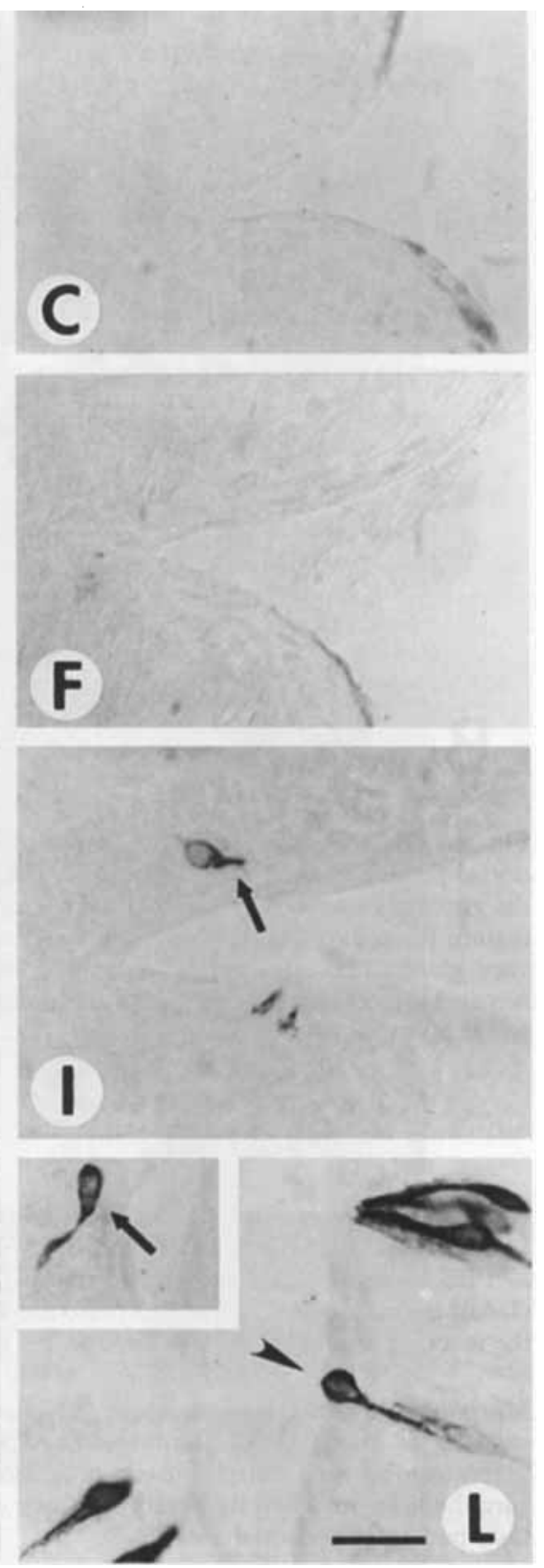

Fig. 3A-L. Immunoreactivity for keratins 8,7 , and 18 in neonatal vallate papillae at postnatal days $0,1,2$, and 3 (A-L). A At P0 there were polygonal taste cells immunoreactive only for keratin 8 (arrow). At P0 there was no immunoreactivity for keratin 7 (B), or keratin 18 (C). By P1 (D), taste cells (arrow) and the luminal surface of circular expansions of the developing trench were keratin8-positive. At P1 (E) there were keratin-7-positive polygonal cells but no keratin-18-positive cells (F). G-I At P2 there were taste cells reactive for keratin 7,8, and 18. At P2 and P3 several taste cells were oriented roughly parallel to the trench (arrows in $\mathbf{H}, \mathbf{I}$ and inset in $\mathbf{L}$ ). Taste cell nuclei occasionally migrated to the surface of the trench (arrowhead in $\mathbf{L}$ ). The scale bar in $\mathrm{L}$ is $50 \mu \mathrm{m}$ for $\mathbf{A}-\mathbf{L}$
PKK3 to keratin 18 (Labsystems, [18]), and MAb Bul/75 to BrdU (Sera-Lab, from Accurate Chemical Sci.).

Immunohistochemistry was carried out using an avidin-biotin peroxidase $(A B C)$ method (Vector Labs). For the $A B C$-peroxidase method, mounted tissue sections were hydrated in four 5-min

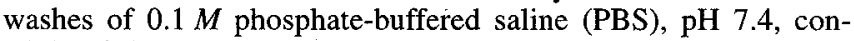
taining $0.4 \%$ Triton-X 100 (TX-100, Sigma). The slides were then incubated for $30 \mathrm{~min}$ with $3 \%$ normal goat serum (Cappel, Organon Teknika) in PBS/TX-100, followed by a 1-h incubation with the primary antibody at room temperature. The slides were washed with PBS four times for 5 min each, followed by a $45-\mathrm{min}$ application of the secondary antibody, biotin-conjugated goat antimouse IgG preadsorbed with rat serum proteins (B-8774, Sigma). Three additional washes in PBS preceded both the 30-min appli- 


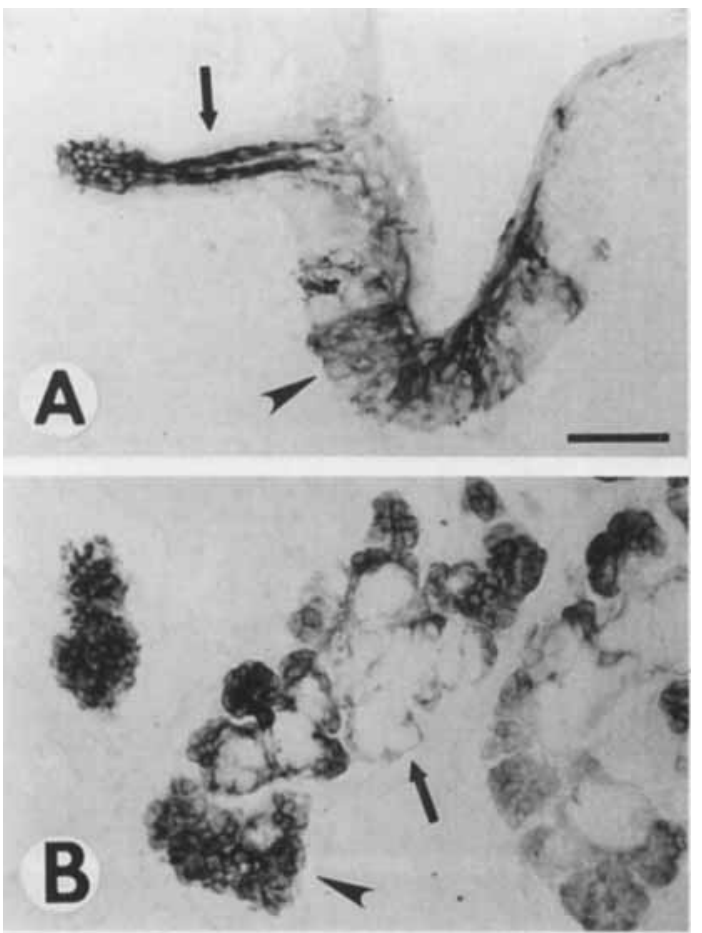

Fig. 4A, B. A A salivary duct (arrow) at P3 is connected to the dorsal portion of the vallate trench. Regions of diffuse staining of the gustatory trench (arrowhead) were a temporary developmental feature limited to keratin 8 . B Only for keratin 8 were serous salivary glands beneath the vallate papilla immunopositive (arrowhead). Mucus glands were always immunonegative (arrow). Scale bar is $50 \mu \mathrm{m}$ for $\mathbf{A}$ and $\mathbf{B}$

cation of Vectastain avidin-biotin complex (PK-4000 kit, Vector Laboratories, Burlingame, CA) and the 5-10 min incubation with a PBS solution containing $0.5 \mathrm{mg} / \mathrm{ml} \quad 3,3^{\prime}$-diaminobenzidine (DAB, Sigma), $0.01 \%$ hydrogen peroxide and $0.04 \% \mathrm{NiCl}_{2}$ to tint the reaction product blue.

Morphometric analysis. We analyzed photographs of transverse sections of the apex of immunostained taste buds. We used a graphics tablet and morphometric program (Sigma Scan) to measure the area occupied by keratin-positive cells as a percentage of taste bud cross-sectional area.

BrdU injection and detection of BrdU and Keratin 18 or 19. At 9 a.m. on day 0 adult rats were injected intraperitoneally with 5-bromo-2'-deoxy-uridine (BrdU, Sigma) at $25 \mathrm{mg} /$ rat ( $n=9$ rats) or 5 $\mathrm{mg} / \mathrm{rat}$ ( $n=7$ rats). Rats were euthanized $1 \mathrm{~h}$, and $1,2,3,4$, and 5 days after BrdU injection. Mounted, $10 \mu \mathrm{m}$ thick, tongue sections were denatured in $2 \mathrm{~N} \mathrm{HCl}$; hydration in PBS/TX-100 preceded (four 4-min washes) and followed (three 10-min washes) the DNA denaturation. A 60-min incubation with anti-BrdU antibody (1:20, Accurate Chemical and Scientific Corp.) was followed by the secondary antibody, biotin-sp-conjugated goat anti-rat IgG (1:1000, Jackson ImmunoResearch Lab.). After three 4-min washes in PBS, the slides were subjected to a 30-min application of the Vectastain avidin-biotin complex. Prior to treatment with $\mathrm{DAB} /$ nickel chloride, the sections were exposed for $30 \mathrm{~min}$ to $1 \%$ cobalt chloride. Next the sections were subjected to the protocol described above for keratin staining, except that the nickel chloride was omitted. The BrdU-labeled nuclei were blue while the keratin 18 or keratin 19-like immunoreactivity was yellow/brown.
The seven rats injected with $5 \mathrm{mg}$ BrdU provided the quantitative data. Fifty taste buds were each examined $1 \mathrm{~h}$ and 1 day after BrdU injection. One hundred taste buds were examined on each of days 2-5.

\section{Resuits}

All, or almost all, intragemmal cells were immunoreactive for keratins 7, 8, and 19. In contrast, using MAb $L E 65$ (keratin 18) fewer than half of the intragemmal cells were immunoreactive in adult taste buds of rat tongue, palate, nasopalatine papilla, and epiglottis (Fig. 1). Similar results for keratin-18-like immunoreactivity were obtained with MAb $P K K 3$ for vallate and foliate taste cells.

In cross-sections of vallate taste buds, the MAbs for keratins 7, 8, and 19 generated immunopositive rings or disks. A complete ring of stained cells was present when the cross-section passed through the taste pit. A solid disk, except for the outer margins, was present when the cross-section passed immediately beneath the taste pit (Fig. 2A, B). There were no well-formed rings or disks after immunostaining for keratin 18. Instead, cross-sections of keratin-18-positive cells were scattered among frequent voids and took no preferred position within the circular cross-section of the taste bud (Fig. 2C-D).

We evaluated cross-sections immediately below the taste pit in our first method of quantifying the extent of keratin 18 staining. We measured the percentage of a taste bud's cross-sectional area that was stained for a specific keratin. The mean percentages were $98 \% \pm 1 \%$ for keratin $8, n=12$ buds and $40 \% \pm 8 \%$ for keratin 18 , $n=9$ buds $(P<0.01, t$ test $)$. Taste cells were not counted in cross-section, because the cell boundaries could not be confidently discerned.

To count cells, we counted the nuclei of keratin-18positive cells in serial, longitudinal sections (Fig. 2E-G). (Antibodies for keratins 7, 8 and 19 stained so ubiquitously that it was impossible to identify unstained intragemmal cells.) There was a mean of $19 \pm 5$ keratin-18positive intragemmal cells per vallate taste bud (mean \pm sd nuclei, uncorrected for split nuclei, $n=46$ buds). Small taste buds had as few as 10 keratin-18-positive cells; the largest buds had up to 27 . Since rat vallate taste buds have a mean of 75 intragemmal cells [11], about $25 \%$ of the intragemmal cells are keratin 18-positive. Taste buds elsewhere in the oral cavity had comparable numbers of keratin-18-positive taste cells. However, there was wide variation among fungiform taste buds-some had as few as five keratin-18-positive cells.

We examined the developmental occurrence of keratins $7,8,18$, and 19 in the vallate papilla at birth (postnatal day $0=P 0$ ), and at P1, P2, P3, P4, and P6. From P0-P6 immunoreactivity for keratin 19 (not shown) and keratin 7 developed in tandem. At P0 staining for keratins 7,18 , and 19 was negative, but for keratin 8 there were a few immunoreactive salivary duct cells and polygonal taste cells (no marked elongation). By P1 the immunoreactivity of vallate trench cells included keratins 7 and 19. At P2 isolated keratin-18-positive cells were occasionally observed; they were always elongated. It was not until P2-P3 that taste cells regularly ex- 

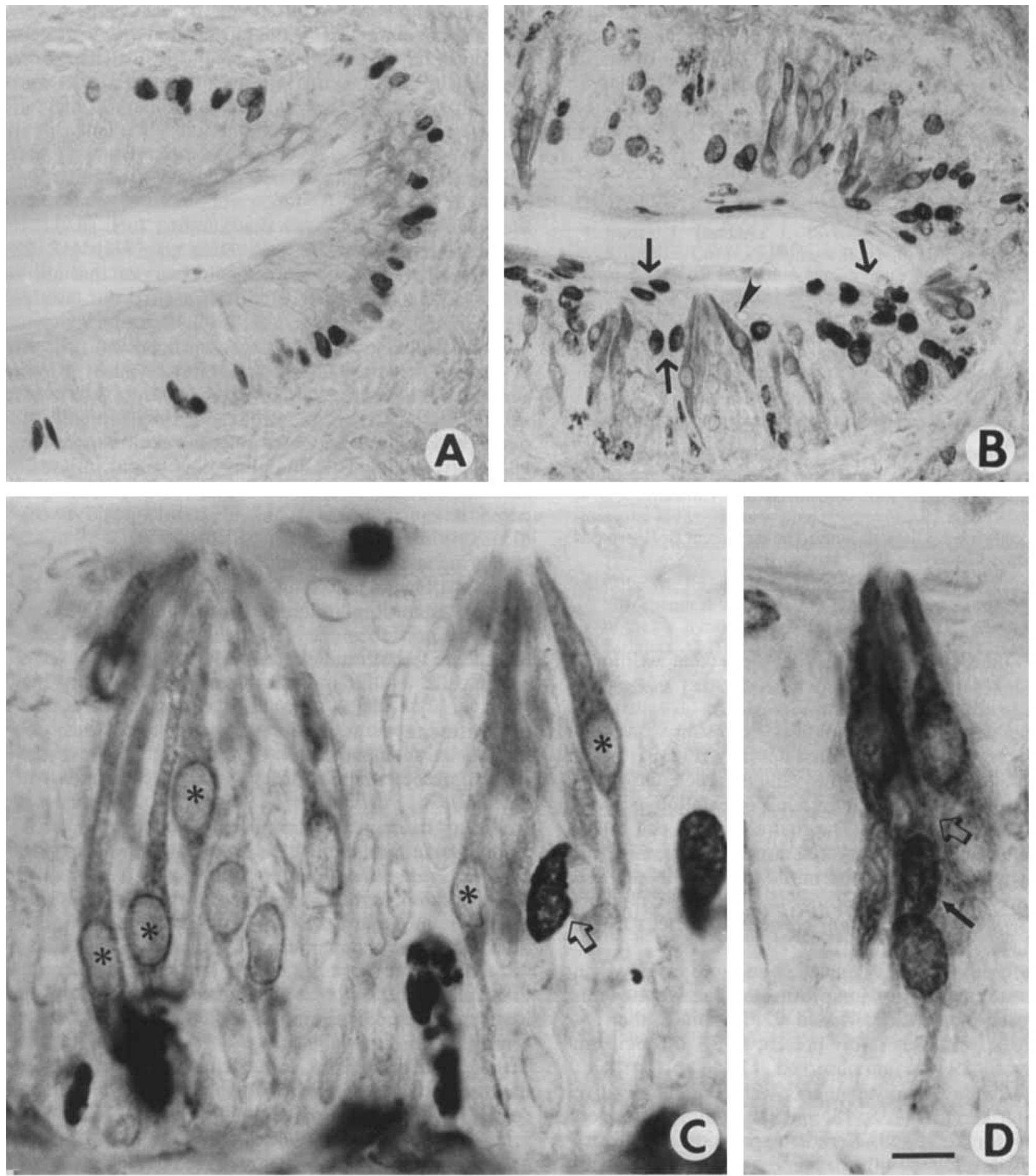

Fig. 5A-D. Animals were euthanized at time $t$, after bromodeoxyuridine (BrdU) injection. A At $t=1 \mathrm{~h}$, BrdU-labeled cells were restricted to the basal layer. B By $t=2$ days, labeled cells had migrated toward the trench surface (arrows). One of several keratin-18positive cells is evident (arrowhead). C At $t=2$ days, a BrdU-positive, keratin-18-negative cell is present in a taste bud (open ar- row). Five keratin-18-positive cells with BrdU-negative nuclei (asterisks) are prominent. D A taste bud at $t=4$ days contains a keratin-18-positive cell (open arrow) with a BrdU-positive nucleus (solid arrow). Scale bar in D is $25 \mu \mathrm{m}$ for A, B and $8 \mu \mathrm{m}$ for C, D 


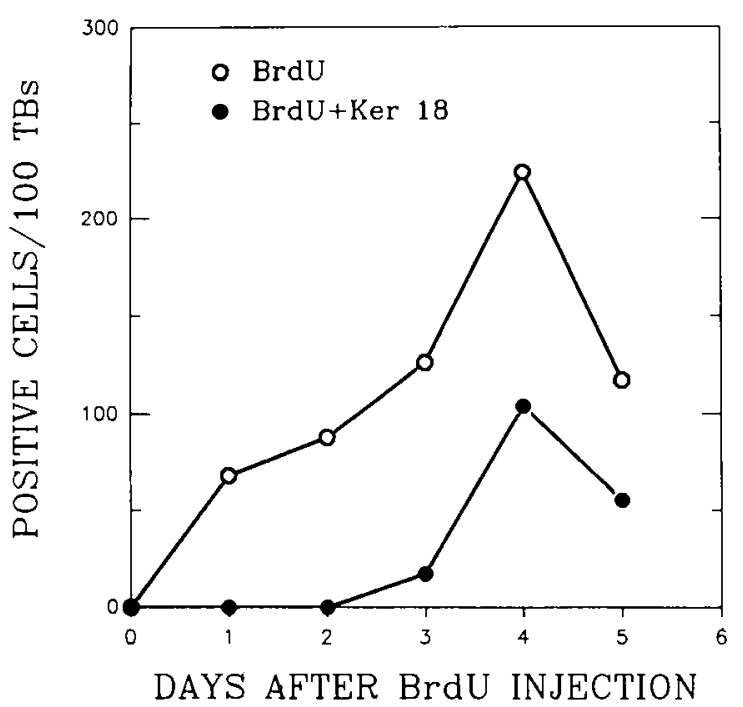

Fig. 6. The number of BrdU-labeled and double-labeled intragemmal cells per 100 taste buds increased as a function of days after BrdU injection. Animals were euthanized after $1 \mathrm{~h}$ and $1,2,3,4$, and 5 days. Keratin 18 immunoreactivity was present in intragemmal taste cells aged 3 days or more. The decline in BrdU-labeled cells at 5 days may reflect BrdU toxicity

tended to the trench surface. By P3 there were additional dispersed keratin-18-positive cells; clusters of several elongated cells were also seen (Fig. 3J-L).

During development the apical extension of vallate taste cells was generally directed dorsally (Fig. 3J). With continued downgrowth of the vallate trench the intragemmal cells shifted into their adult orientation-perpendicular to the trench wall. The first elongated cell to appear was typically a solitary cell. Apparent errors in positioning were observed: the initial elongated taste cell might have its long axis parallel to the trench wall surface or less commonly might elevate its nucleus to the trench surface (Fig. 3H, I, L).

Fungiform taste buds developed no more rapidly than vallate taste buds. Fifty fungiform papillae were examined at each of ages P0, P1 and P2. Keratin 8, the first keratin to appear, was rarely present at $\mathrm{P} 1$ in fungiform cells. Keratin 19 was first observed at P2.

Mature cells of salivary ducts were immunopositive for all four keratins $(7,8,18$, and 19) with the strongest reactivity for keratin 8 . Keratin expression in salivary duct cells developed with the same timing and sequencing as for taste cells. In neonates some salivary ducts entered the upper portion of the vallate trench (Fig. 4A). In young animals the salivary glands were mixed clusters of immunonegative mucous secreting cells and immunopositive (only for keratin 8) serous cells (Fig. 4B). Neither type of salivary gland cell acquired immunoreactivity for keratins 7,18 , or 19 .

In adult rats, cell division monitored by BrdU was conspicuously associated with basal cells. Within 1 day after BrdU injection, some fusiform intragemmal cells were double-labeled for BrdU and keratin 19. By 2 days numerous BrdU-positive cells had reached the surface of the epithelium between taste buds. By 3 days there were a few intragemmal cells double labeled for BrdU and keratin 18. It was not until 4 days after BrdU injection that cells double-labelled for BrdU and keratin 18 were regularly observed (Figs. 5, 6).

\section{Discussion}

We have previously shown that keratins $7,8,18$ and 19 are present in rat, gerbil, and rabbit taste buds [13, 25 , 37]. Here, we have confirmed observations that all, or nearly all, intragemmal cells that reached the taste pit were immunopositive for keratins 7, 8, and 19. Apical sections excluded those younger intragemmal cells not yet extending to the taste pit. Keratin-18-positive intragemmal cells were older; they were at least 3 days old. Hence, sections at the level of the taste pit might overrepresent keratin-18-positive cells in relation to keratin18-negative cells. This sampling bias would inflate the keratin-18-positive cross-sectional area (40\%) compared to nuclear counts of keratin-18-positive cells (25\%).

During taste bud development keratin 18 was not detected in taste cells until 2-3 days after keratins 7, 8 and 19. Accordingly, keratin 18 immunoreactivity was restricted to elongated taste cells. Similarly, during adult taste cell turnover, keratin 18 was rarely detected in cells less than 4 days old. With a lifespan of 10 days [7], vallate taste cells could spend $60 \%$ of their lifespan with keratin 18 (4-10 days). Since only $25 \%$ of intragemmal cells were keratin 18-positive, they must represent a subset of intragemmal cells aged 4-10 days.

The percentage of keratin-18-positive cells varied among vallate taste buds. We estimate that after normalization for taste bud volume, there remained up to a twofold variation in the abundance of keratin-18-positive cells. Some of this variation may be statistical fluctuation in the cell population age structure across vallate taste buds. Fungiform taste cells turn over more rapidly than vallate taste cells $[2,7]$. This could contribute to the lower number of keratin-18-positive cells observed in some fungiform taste buds.

MAbs $L E 65$ and $P K K 3$ detected keratin-18-like immunoreactivity in fewer than half of the intragemmal cells. The younger intragemmal cells may have been unstained because they contain little keratin 18 or because the keratin 18 is conformationally or biochemically altered $[14,32]$. Where keratin 18 is present it is likely to modulate the abundance of other keratin polypeptides $(7,8$, and 19$)$. The proportions of keratins 7,8 , 18,19 are known to differ with cell type in other tissues $[6,12,14]$. As a rule, pairs of basic (keratins 1-8) and acidic (keratins 10-19) keratin polypeptides form heterodimers $[16,36]$. If intragemmal cells obey this rule, regulation of keratin 7,8 , or 19 would adjust to accommodate the up-regulation of keratin 18 in older cells. Conceivably, keratin 18 might form heterotrimers, like $8 / 18 / 19,7 / 8 / 18$, and $7 / 8 / 19$, known in other simple epithelial cells $[3,6]$. 
Keratins 7,8 , and 19 are expressed when the developing taste cell is still polygonal. Only later does the nucleus migrate and the taste cells extend apical and basal processes. Keratins may be permissive for cell elongation and migration, or they may contribute strength and rigidity that assist in the extension of cell processes and in tissue penetration.

Previous studies have demonstrated that developing vallate taste buds require about 10 days to form a taste pore [22]. This pace has been confirmed for fungiform taste buds [17]. By continuing to add cells, vallate taste buds ultimately doubled the number of fusiform cells that were present when the pore formed [11]. Keratin staining has revealed that the intragemmal cell assemblage begins as one or two elongated cells. The assemblage of fusiform cells, known as a taste bud, appears to develop and enlarge by the prolonged sequential addition of individual cells rather than by the synchronous conscription and elongation of a cluster of polygonal cells.

Taste bud development does not mirror taste cell turnover or regeneration [23]. In the present research the keratin 7,8 , or 19 -positive polygonal cells observed in development were not detected in adults. Such polygonal cells may be unique to development. Alternatively they may be obscured by the ubiquitous keratin-positive intragemmal cells in adults, or have a fleeting existence given the faster pace of differentiation during adult taste cell replacement and regeneration. Within one day an adult basal cell can give rise to a replacement cell that enters the taste bud, elongates, and expresses keratin 19. Regeneration of an entire taste bud after reinnervation may require only $2-3$ days in an adult vs 10 days for development $[4,5,22]$.

The spatial errors observed during the development of taste buds, such as having the cell axis parallel to the trench wall, appear to have been eliminated in adult taste cells.

Previous studies of taste bud development showed that P0 rats have no vallate taste buds with a pore to the epithelial surface $[11,22]$. We employed antibodies against keratins 8 and 19 to determine that individual taste cells only extended to the trench surface by P2-P3, not at P0 or P1. Examination of the palate at P2 indicated a similar rate of taste bud development (unpublished observations). These findings suggest that the rat's oral taste system is too immature to respond to milk (lactose) at birth [23]. However, the fungiform epithelium is leaky at P7, shortly before taste pores appear. At that time, slow chemical modulation of nerve endings may be possible [17]. Electrophysiological recording at birth would directly evaluate taste axon sensitivity and response latency to lactose.

Salivary duct cells are the only other lingual cells with keratins $7,8,18$, and 19 . The development of keratin immunoreactivity follows the same progression in taste cells and salivary duct cells: positive staining at P0 for keratin 8, at P1 for keratins 7 and 19, and at P2 for keratin 18. The ducts of von Ebner's salivary glands merge with the vallate and foliate trench epithelium. Taste buds have been reported in salivary ducts and may regenerate from salivary duct tissue [29]. These studies of tissue structure, keratin expression patterns, and taste bud regeneration point to the communality of cells comprising the von Ebner's salivary ducts and gustatory trenches [8]. It is possible that some taste cells and salivary duct cells arise from the same founding population.

\section{References}

1. Bartek J, Bartkova J, Taylor-Papadimitriou J, Rejthar A, Kovarik J, Lukas Z, Vojtesek B (1986) Differential expression of keratin 19 in normal human epithelial tissues revealed by monospecific monoclonal antibodies. Histochem J 18:565575

2. Beidler LM, Smallman RL (1965) Renewal of cells within taste buds. J Cell Biol 27:263-272

3. Blumenberg M (1993) Molecular biology of human keratin genes. In: Darmon M, Blumenberg M (eds) Molecular biology of the skin: the keratinocyte. Academic Press, New York, pp. $1-32$

4. Cheal ML, Dickey WP, Jones LB, Oakley B (1977) Taste fiber responses during reinnervation of fungiform papillae. J Comp Neurol 172:627-646

5. Cheal ML, Oakley B (1977) Regeneration of fungiform taste buds: temporal and spatial characteristics. J Comp Neurol 172:609-626

6. Colic M, Jovanovic S, Mitrovic S, Dujic A (1989) Immunohistochemical identification of six cytokeratin-defined subsets of the rat thymic epithelial cells. Thymus 13:175-185

7. Farbman AI (1980) Renewal of taste bud cells in rat circumvallate papilla. Cell Tissue Kinet 13:349-357

8. Fradkina TM, Chelyshev YA (1990) Immunocytochemistry of keratins in tongue mucosa of the rat. Bull Exp Biol Med $110: 323-325$

9. Franke WW, Schmid E, Schiller DL, Winter S, Jarash ED, Moll R, Denk H, Jackson B, Illmensee K (1982) Differentiation-related patterns of expression of proteins and intermediate-sized filaments in tissues and cultured cells. Cold Spring Harbor Symp Quant Biol 46:431-453

10. Gigi-Leitner O, Geiger B (1986) Antigenic interrelationship between the 40-kilodalton cytokeratin polypeptide and desmoplakins. Cell Motil Cytoskel 6:628-639

11. Hosley MA, Oakley B (1987) Postnatal development of the vallate papillae and taste buds in rats. Anat Rec 218:216222

12. Kasper M, Rudolf T, Verhofstad AAJ, Schuh D, Muller M (1993) Heterogeneity in the immunolocalization of cytokeratin-specific monoclonal antibodies in the rat lung: evaluation of three different alveolar epithelial cell types. Histochemistry 100:65-71

13. Knapp L, Lawton A, Oakley B, Wong L, Zhang C (1995) Keratins as markers of differentiated taste cells of the rat. Differentiation 58:341-349

14. Kuijpers W, Peters TA, Tonnaer ELGM, Ramaekers FCS (1991) Expression of cytokeratin polypeptides during development of the rat inner ear. Histochemistry 96:511-521

15. Lane EB (1982) Monoclonal antibodies provide specific intramolecular markers for the study of epithelial tonofilament organization. J Cell Biol 92:665-673

16. Lane EB, Alexander CM (1990) Use of keratin antibodies in tumor diagnosis. Cancer Biol 1:165-179

17. Mbiene JP, Farbman AI (1993) Evidence for stimulus access to taste cells and nerves during development: an electron microscopic study. Microsc Res Tech 26:94-105

18. Moll R, Franke WW, Schiller D, Geiger B, Krepler R (1982) The catalog of human cytokeratins: patterns of expression in normal epithelia, tumors and cultured cells. Cell 31:11-24

19. Morgan PR, Leigh IM, Purkis PE, Gardner ID, Van Muijen GNP, Lane EB (1987) Site variation in keratin expression in 
human oral epithelia-an immunocytochemical study of individual keratins. Epithelia 1:31-43

20. O'Guin WM, Galvin S, Schermer A, Sun TT (1987.) Patterns of keratin expression define distinct pathways of epithelial development and differentiation. Curr Top Dev Biol 22:97124

21. O'Guin WM, Schermer A, Lynch M, Sun TT (1990) Differentiation-specific expression of keratin pairs. In: Goldman RD, Steinert PM (eds) Cellular and molecular biology of intermediate filaments. Plenum Press, New York, pp. 301-334

22. Oakley B (1991) Neuronal-epithelial interactions in mammalian gustatory epithelium. In: Whelan J (ed) Regeneration of Vertebrate Sensory Receptor Cells. Ciba Foundation Symposium, pp. 277-293

23. Oakley B (1993) Control mechanisms in taste bud development. In: Simon SA Roper SD (eds) Mechanisms of Taste Transduction. CRC Press, Boca Raton, FL., USA pp. 105-125

24. Oakley B, Lawton A, Riddle DR, Wu LH (1993) Morphometric and immunocytochemical assessment of fungiform taste buds after interruption of the chorda-lingual nerve. Microsc Res Tech 26:187-195

25. Oakley B, Lawton A, Wong L, Zhang C (1994) Keratin polypeptides and taste buds. In: Kurihara K, Suzuki N, Ogawa H (eds) Olfaction and Taste XI. Springer-Verlag, Tokyo, pp. 16-19

26. Oakley B, Schafer R (1978) Experimental Neurobiology. Univ of Michigan Press, Ann Arbor, p. 355

27. Quinlan RA, Schiller DL, Hatzfeld M, Achtstätter T, Moll R, Jorcano JL, Magin TM, Franke WW (1985) Patterns of expression and organization of cytokeratin intermediate filaments. Ann NY Acad Sci 455:282-306

28. Ramaekers F, Huysmans A, Schaart G, Moesker O, Vooijs P (1987) Tissue distribution of keratin 7 as monitored by a monoclonal antibody. Exp Cell Res 170:235-249
29. Sanchez BF, Rodrigo Angulo M, Cano Garcia J, RodriguezEchandia EL (1978) Regeneration of the vallate papilla in the rat with special reference to the origin of the taste bud-bearing epithelium. Cell Tissue Res 193:399-411

30. Sawaf MH, Ouhayoun JP, Forest N (1991) Cytokeratin profiles in oral epithelia: a review and a new classification. $J$ Biol Buccale 19:187-198

31. Sawaf MH, Ouhayoun JP, Shabana AHM, Forest N (1990) Cytokeratin expression in human tongue epithelium. Am J Anat 189:155-166

32. Schaafsma HE, Ramaekers FCS, Myen van GNP, Ooms ECM, Ruiter DJ (1989) Distribution of cytokeratin polypeptides in epithelia of the adult human urinary tract. Histochemistry 91:151-159

33. Sun TT, Tseng SCG, Huang AJ-W, Cooper D, Schermer A, Lynch MH, Weiss R, Eichner R (1985) Monoclonal antibody studies of mammalian epithelial keratins: a review. Ann NY Acad Sci 445:307-329

34. Takeda M, Obara N, Suszuki Y (1990) Keratin filaments of epithelial and taste-bud cells in the circumvallate papillae of adult and developing mice. Cell Tissue Res 260:41-48

35. Toh H, Rittman G, Mackenzie IC (1993) Keratin expression in taste bud cells of the circumvallate and foliate papillae of adult mice. Epithel Cell Biol 2:126-133

36. Trevor K, Linney E, Oshima RG (1987) Suppression of endo $B$ cytokeratin by its antisense RNA inhibits the normal co-expression of the endo A cytokeratin. Proc Natl Acad Sci USA 84:1040-1044

37. Wong L, Oakley B, Lawton A, Shiba Y (1994) Keratin 19-like immunoreactivity in receptor cells of mammalian taste buds. Chemical Senses 19:251-264 